\title{
СТАНДАРТИЗАЦІЯ СУХОГО ЕКСТРАКТУ СТУЛОК КВАСОЛІ ЗА ВМІСТОМ ФЛАВОНОЇДІВ
}

Вступ. Створення нових лікарських засобів для лікування та профрілактики цукрового діабету завдання, яке набуває все більшої актуальності за умов зростання захворюваності на діабет. Відомою $\epsilon$ цукрознижувальна дія відварів стулок квасолі. Розробка технології сухого екстракту стулок квасолі, вивчення його гіпоглікемічної дії не можливі без встановлення складу екстракту і його стандартизації.

Мета дослідження - розробка методики ідентифрікації сухого екстракту стулок квасолі; розробка методики кількісного визначення фрлавоноїдів; напрацювання критеріїв якості екстракту.

Методи дослідження. Якісний склад фрлавоноїдів досліджували хроматографрічними методами, кількісне визначення здійснювали спектрофотометричним методом.

Результати й обговорення. Дослідження френольних сполук сухого екстракту стулок квасолі хроматографрічними методами дозволили ідентифрікувати рутин, ізокверцитрин, кислоту фрерулову, а також у слідовій кількості кверцитрин. Крім зазначених френольних сполук, екстракт у значній кількості містить: неідентифрікований фрлавоноїд, зона якого на тонкошаровій хроматограмі розташовується між зонами рутину і кислоти хлорогенової; дві гідроксикоричні кислоти, зони яких знаходяться нижче і вище зони кислоти фрерулової та, ймовірно, можуть бути їі похідними; неідентифріковану гідроксикоричну кислоту, зона якої розташовується одразу над зоною рутину. Аналіз електронних спектрів поглинання розчину стандартного зразка рутину і випробовуваного розчину сухого екстракту за умов кількісного визначення з алюмінію хлоридом дозволив застосувати рутин як стандарт для розрахунку вмісту срлавоноїдів. Вміст фрлавоноїдів було визначено спектрофотометричним методом, він становив 0,70-0,78 \% у перерахунку на рутин і суху речовину для різних серій екстракту.

Висновки. Для ідентифрікації сухого екстракту стулок квасолі активними маркерами запропоновано обрати рутин, ізокверцитрин і кислоту ферулову. Запропоновано схему хроматограми, якій повинна відповідати хроматограма випробовуваного розчину при ідентифрікації сухого екстракту. Кількісним критерієм якості запропоновано вміст фрлавоноїдів - не менше 0,65 \% у перерахунку на рутин і суху речовину.

КЛЮЧОВІ СЛОВА: стулки квасолі; сухий екстракт; фрлавоноїди; стандартизація.

ВСТУП. Стандартизація лікарської рослинної сировини (ЛРС) і екстрактів на її основі, відповідно до фрармакопейних вимог, пов'язана з вибором біологічно активних речовин для ідентифікації лРС/екстракту та встановлення кількісного критерію [1]. Віддавна відомою $€$ цукрознижувальна дія відварів стулок квасолі [2], а також гіполіпідемічна та гіпоглікемічна дія екстрактів з насіння квасолі різних видів і сортів, отриманих у різний спосіб [3-8]. Кожна розробка технології екстракту, вивчення його гіпоглікемічної дії не можливі без встановлення складу екстракту і його стандартизації. Відтворюваність біологічної дії екстракту закономірно пов'язана з відтворюваністю хімічного складу композиції біологічно активних речовин (БАР). Розробка технології - вибір оптимальних умов і кращих технологічних параметрів спирається на резульс Л. В. Вронська, 2018. тати визначення складу і вмісту БАР та пов'язану з ними біологічну активність. Кінцево не визначено клас речовин, з яким пов'язують цукрознижувальну дію як стулок квасолі, так і квасолі трави чи квасолі насіння. Є повідомлення про отримання екстракту з трави з коренями квасолі, й він також виявляв гіпоглікемічну дію [9]. Серед БАР трави, стулок і насіння квасолі вагомим класом сполук є фрлавоноїди та гідроксикоричні кислоти, які, за різними джерелами, можуть виявляти гіпоглікемічну і гіполіпідемічну дію [10, 11]. Попереднє вивчення складу і вмісту цих сполук у стулках квасолі показало, що вони представлені рутином, ізокверцитрином та кислотою фреруловою, агліконовий склад фрлавоноїдів - кверцетином і незначною кількістю кемпоеролу [12].

Продовжуючи стандартизацію у ланцюзі ЛРС - екстракт, було розглянуто можливість 
вибору фрлавоноїдів як активних маркерів для стандартизації сухого екстракту стулок квасолі.

Мета дослідження - розробка методики ідентисрікації сухого екстракту стулок квасолі; розробка методики кількісного визначення фрлавоноїдів; напрацювання критеріїв якості екстракту.

МЕТОДИ ДОСЛІДЖЕННЯ. При ідентифрікації фрлавоноїдів хроматографічними методами застосовували: стандартні зразки рутину, гіперозиду, апігенін-7-глюкозиду, лютеолін-7-глюкозиду, ізокверцитрину, кверцитрину, лютеоліну, кверцетину, кемпферолу, хлорогенової, фрерулової і кофрейної кислот (Sigma-Aldrich, Fluka); хроматограсрічні пластинки Silica gel $60 \mathrm{~F}_{254}$ та хроматограсрічні камери (“Merck", Німеччина), приладдля нанесення проб Linomat 5 і ультрасріолетову камеру для перегляду хроматограм (“CAMAG”, Швейцарія), рідинний хроматограср Agilent 1200 з діодно-матричним детектором (“Agilent”, США). Вміст фрлавоноїдів визначали спектрофоотометрично, записуючи електронні спектри поглинання на спектрофотометрі Lambda 25 ("PerkinEImer", США). Хроматографрічні дослідження методом високоесрективної рідинної хроматограсрії (ВЕРХ) проведено за умов, які детально було описано раніше [13].

Усі реагенти і розчинники, з яких готували розчини або рухомі фрази чи які застосовували при визначенні кількісного вмісту, відповідали вимогам ДФУ [1].

РЕЗУЛЬТАТИ Й ОБГОВОРЕННЯ. ВИВЧеННЯ складу фенольних сполук сухого екстракту стулок квасолі методом тонкошарової хроматографрії проводили із застосуванням різних систем розчинників, використаних раніше при дослідженнях фрлавоноїдів ЛРС стулок квасолі. Кращими для розділення БАР екстракту виявились системи: 1 - мурашина кислота-вода-етилацетат (6:9:90) і 2 - мурашина кислота - льодяна оцтовакислота - вода -етилацетат $(7,5: 7,5: 17: 67,5)$. В обох системах розчинників однозначно ідентифрікуються рутин, ізокверцитрин і кислота фрерулова, як і було у відповідній ЛРС. В обох системах розчинників на отриманих хроматограмах найбільш інтенсивною $€$ зона жовто-оранжевої фрлуоресценції, яка розташовується між зонами рутину та кислоти хлорогенової і належить неідентифрікованому фрлавоноїду. Крім того, в першій системі розчинників добре виявляються, додатково до ферулової, ще три гідроксикоричні кислоти; дуже інтенсивна блакитно-фріолетова зона однієї 3 них розташовується одразу над рутином, інтенсивні фріолетово-блакитні зони двох інших розміщуються вище і нижче кислоти фрерулової. У другій системі розчинників БАР екстракту більш розчинні, завдяки чому їх зони розташовуються вище, порівняно з першою системою, і це дозволило виявити ще одну сполуку фрлавоноїдів невстановленого складу, за інтенсивністю фрлуоресценції якої можна зробити висновок про незначну її кількість в екстракті порівняно з іншими такими ж сполуками. Ця речовина не виявлялася в першій системі розчинників через, очевидно, низьку розчинність у ній, завдяки чому практично залишалася поблизу лінії старту.

Результати ВEPX-вивчення складу вказують на наявність рутину, ізокверцитрину і кислоти срерулової, незначної кількості кверцитрину в сухому екстракті. За відсутності більшої кількості зразків стандартів фрлавоноїдів і гідроксикоричних кислот ідентифікувати інші, присутні на BEPX-хроматограмах, піки речовин не було можливим при використанні діодно-матричного детектора.

Таким чином, при стандартизації сухого екстракту стулок квасолі ідентифрікаційними активними маркерами необхідно обрати рутин та ізокверцитрин, з фрлавоноїдів, і кислоту фрерулову. В схемі хроматограми, при ідентисрікації сухого екстракту, потрібно зазначити додатково обов'язкову присутність інтенсивної зони з жовто-оранжевою фрлуоресценцією, що відповідає неідентифрікованому фрлавоноїду, та інтенсивної блакитно-фріолетової зони, що відповідає неідентисрікованій гідроксикоричній кислоті.

Зважаючи на низький вміст кверцитрину в екстракті, присутність його зони на хроматограмі випробовуваного розчину, недоцільно вводити як обов'язковий ідентифікаційний критерій сухий екстракт стулок квасолі.

При стандартизації сухого екстракту стулок квасолі було запропоновано таку методику його ідентифрікації.

Методика ідентифікації флавоноїдів сухого екстракту стулок квасолі.

Випробовуваний розчин. 0,25 г екстракту поміщають у мірну колбу місткістю 10 мл і розчиняють у метанолі $P$, перемішують.

Розчин порівняння. 0,5 мг С3 кислоти хлорогенової (Sigma-Aldrich), 0,5 мг С3 рутину (SigmaAldrich), 0,5 мг С3 ізокверцитрину (Sigma), 0,5 мг С3 кислоти фрерулової (Sigma-Aldrich, USP) розчиняють у 10,0 мл метанолу $P$.

Пластинка: ТШХ силікагелева пластинка $P$ (5-40 мкм).

Рухома фраза: кислота мурашина безводна $P$ - вода $P$ - еталацетат P (6:9:90) (об/об).

Нанесення перед хроматографуванням: 40 мкл випробовуваного розчину і 10 мкл розчину порівняння смугами завдовжки 1 см. 
Висушування перед хроматограсруванням: на повітрі.

Відстань, яку має пройти рухома сраза: 12 см.

Висушування перед проявкою: в сушильній шасрі при температурі $100-105^{\circ} \mathrm{C}$ протягом 10 хв.

Виявлення: теплу пластинку обприскують розчином 10 г/л аміноетилового ефріру дифренілборної кислоти Р у метанолі $P$, сушать на повітрі. Потім пластинку обприскують розчином 50 г/л макроголу 400 Р у метанолі P, сушать на повітрі протягом 30 хв і переглядають в УФ-світлі 3 довжиною хвилі 365 нм.

Результати. На хроматограмі розчину порівняння повинні виявлятися (в порядку зростання $\mathrm{R}_{\mathrm{f}}$ ): жовто-оранжева фрлуоресціююча зона, відповідна рутину; блакитна фрлуоресціююча зона, відповідна кислоті хлорогеновій; жовто-оранжева фрлуоресціююча зона, відповідна ізокверцитрину; фріолетова фрлуоресціююча зона, відповідна кислоті фреруловій.

На хроматограмі випробовуваного розчину мають виявлятися: жовто-оранжева фрлуоресціююча зона на рівні зони рутину на хроматограмі розчину порівняння; інтенсивна жовто-оранжева фрлуоресціююча зона дещо нижче зони кислоти хлорогенової на хроматограмі розчину порівняння; жовто-оранжева фрлуоресціююча зона на рівні зони ізокверцитрину на хромато- грамі розчину порівняння; інтенсивна зона блакитно-фріолетової фрлуоресценції одразу над зоною рутину; інтенсивна зона фріолетової фрлуоресценції на рівні зони кислоти фрерулової на хроматограмі розчину порівняння та ще дві інтенсивні зони сріолетової фрлуоресценції нижче і вище зони кислоти фрерулової на хроматограмі розчину порівняння. Можуть виявлятися інші зони жовто-оранжевої і фріолетової фрлуоресценції (інші фрлавоноїди і гідроксикоричні кислоти та їх похідні).

Отримані, згідно із запропонованою методикою, результати дослідження дозволили висунути такі вимоги до вигляду хроматограми випробовуваного розчину при ідентисрікації фрлавоноїдів сухого екстракту стулок квасолі (рис.).

Фармакопейний підхід до стандартизації ЛРС, екстрактів і готових лікарських засобів рослинного походження передбачає застосування специфрічних методів ідентифрікації і сумарних методів кількісного визначення. Тому, як і у випадку з ЛРС стулок квасолі, було використано спектрофотометричне визначення суми фрлавоноїдів у перерахунку на рутин. Рутин обрано як стандарт у зв'язку з його присутністю в сировині та екстракті. Вирішальним же критерієм вибору були подібність електронних спектрів поглинання і близькість положення максимумів поглинання для розчину стандартного зразка рутину

\begin{tabular}{|c|c|}
\hline \multicolumn{2}{|c|}{ Верхня частина пластинки } \\
\hline $\begin{array}{l}\text { Кислот а ферулоба: фіолетова } \\
\text { флуоресціююча зона }\end{array}$ & $\begin{array}{l}\text { Фіолетова флуоресціююча зона } \\
\text { Фіолетова флуоресціююга зона } \\
\text { Фіолетова флуоресціююча зона }\end{array}$ \\
\hline $\begin{array}{l}\text { Ізокб ериичрин: жовто-оранжева } \\
\text { флуоресціююча зона }\end{array}$ & Жовто-оранжева фпуоресціююча зона \\
\hline Кислот а хлорогеноба: блакитна & \\
\hline & $\begin{array}{l}\text { Iн тенси вна жовто-оранжева } \\
\text { флуоресціююча зона }\end{array}$ \\
\hline $\begin{array}{l}\text { Pутин: жовто-оранжева } \\
\text { флуоресціююча зона }\end{array}$ & $\begin{array}{l}\text { Блакитно-фіолетова флуоресціююча } \\
\text { зона } \\
\text { Жовто-оранжева фпуоресціююча зона }\end{array}$ \\
\hline Розчин порівн ЛнН Я & Випробовуваний рознин \\
\hline
\end{tabular}

Рис. Схема тонкошарової хроматограми за умов ідентифікації фрлавоноїдів сухого екстракту стулок квасолі після послідовної обробки розчинами аміноетилового ефіру дифенілборної кислоти і макроголу 400 при перегляді в УФ-світлі з довжиною хвилі 365 нм. 
$(\lambda=(412 \pm 2)$ нм $)$ та випробовуваного розчину сухого екстракту $(\lambda=(410 \pm 2)$ нм) за умов кількісного визначення.

Сухий екстракт стулок квасолі - порошок оранжево-коричневого забарвлення, який розчиняється у воді, метанолі, водно-спиртових сумішах. Для приготування вихідного розчину екстракту було обрано етанол (60 \% (об/об)) P. Експериментальним шляхом підібрано оптимальну наважку екстракту для отримання значення оптичної густини випробовуваного розчину $з$ мінімальною інструментальною похибкою, а також оптимальну кількість реагентів та час витримування приготовлених розчинів перед вимірюванням. У результаті попередньо проведених досліджень було запропоновано таку методику.

Методика кількісного визначення фрлавоноїдів у сухому екстракті стулок квасолі.

Вихідний розчин. 0,6 г (точна наважка) екстракту поміщають у мірну колбу місткістю 50 мл, додають 40,0 мл етанолу (60\% (об/об)) P, розчиняють і доводять об'єм розчину етанолом (60 \% (об/об)) $P$ до позначки, перемішують. Отриманий розчин фрільтрують, відкидаючи перші 5 мл фрільтрату.

Випробовуваний розчин. 5,0 мл вихідного розчину поміщають у мірну колбу місткістю 25 мл, додають 3,0 мл 3 \% етанольного (70\% (об/об)) розчину алюмінію хлориду і доводять об'єм розчину етанолом (60 \% (об/об)) Р до позначки, перемішують.

Компенсаційний розчин. 5,0 мл вихідного розчину поміщають у мірну колбу місткістю 25 мл і доводять об'єм розчину етанолом (60 \% (об/об)) Р до позначки, перемішують.

Вихідний розчин рутину. 0,05 г (точна наважка) ДФЗ рутину поміщають у мірну колбу місткістю 100 мл, додають 70 мл етанолу (60\% (об/об)) $P$, розчиняють і доводять об'єм розчину етанолом (60 \% (об/об)) Р до позначки, перемішують.

Розчин порівняння. 1,0 мл вихідного розчину рутину поміщають у мірну колбу місткістю 25 мл, додають 3,0 мл 3 \% етанольного (70 \% (об/об)) розчину алюмінію хлориду і доводять об'єм розчину етанолом (60 \% (об/об)) Р до позначки, перемішують.

Компенсаційний розчин до розчину порівняння. 1,0 мл вихідного розчину рутину поміщають у мірну колбу місткістю 25 мл і доводять об'єм розчину етанолом (60 \% (об/об)) Р до позначки, перемішують.

Через 45 хв вимірюють оптичну густину випробовуваного розчину і розчину порівняння відносно своїх компенсаційних розчинів на спектросоотометрі при довжині хвилі 410 нм.
Вміст суми фрлавоноїдів (X, \%) у сухому екстракті стулок квасолі, в перерахунку на рутин і суху речовину, розраховують за фрормулою:

$$
\mathrm{X}=\frac{m_{0} \cdot A \cdot 10 \cdot 100}{A_{0} \cdot m \cdot(100-\mathrm{W})},
$$

де $m_{0}$ - маса наважки ДФЗ рутину, г;

$m$ - маса наважки екстракту, взятого для аналізу, г;

$A$ - оптична густина випробовуваного розчину;

$A_{0}$ - оптична густина розчину порівняння;

$W$ - втрата в масі при висушуванні екстракту, \%.

Запропоновану методику було апробовано на різних серіях сухого екстракту, а результати визначення наведено в таблиці.

Таблиця - Результати визначення вмісту фрлавоноїдів у сухому екстракті стулок квасолі $(P=0,95, n=5)$

\begin{tabular}{|c|c|}
\hline Серія екстракту & Вміст фрлавоноїдів, \% \\
\hline 1 & $0,705 \pm 0,020$ \\
\hline 2 & $0,716 \pm 0,014$ \\
\hline 3 & $0,729 \pm 0,019$ \\
\hline 4 & $0,777 \pm 0,021$ \\
\hline 5 & $0,741 \pm 0,016$ \\
\hline
\end{tabular}

Отримані для різних серій результати аналізу є близькими між собою, що свідчить про стійкість технології екстрагування і наступних технологічних процедур, застосованих при одержанні сухого екстракту. Також цей розкид результатів дозволяє запропонувати в першому наближенні критерій якості сухого екстракту за вмістом фрлавоноїдів - не менше 0,65 \%.

Описані в літературі екстракти квасолі (отримувані з різних частин рослини й у різний спосіб) не були стандартизовані за вмістом фрлавоноїдів, оскільки в більшості випадків застосовували екстракцію подрібненого насіння, переважно білих сортів, водою (холодною/киплячою) з додаванням реагентів для створення буфера 3 бажаним значенням pH [3-7]. Сучасні дослідження френольних профрілів різних видів квасолі $[14,15]$ свідчать про присутність глікозидних фрорм кверцетину і кемпферолу. В [14] вказано значущі відмінності складу фрлавоноїдів для різних видів та сортів квасолі, тоді як профрілі гідроксикоричних кислот є достатньо одноманітними і представлені кислотою фреруловою та ії̈ похідними. Серед фрлавоноїдів у рожевих, чорних та червоних видах і сортах ідентифіковано глікозиди кемпферолу, мірицетину та кверцетину [14] і не досліджено білих сортів і видів. Автори [15] вказують на присутність кемпфрерол 3-О-ксилозил-глюкозиду в білих сортах квасолі, але не на присутність рутину, ізокверцитрину, кверцитрину, як було встановлено у 
[12]. Таким чином, неідентифрікований фрлавоноїд, зона якого на ТШХ-хроматограмі розташовується між зонами рутину і кислоти хлорогенової, може бути кемпрерол 3-О-ксилозил-глюкозидом, оскільки в агліконовому складі стулок квасолі кемпферол присутній.

ВИСНОВКИ. 1. Запропоновані методики ідентифрікації і кількісного визначення срлавоноїдів дозволяють якісно та кількісно визначати сухий екстракт стулок квасолі.
2. Для стандартизації сухого екстракту стулок квасолі ідентифікаційними маркерами обрано рутин, ізокверцитрин і кислоту фрерулову. Запропоновано вигляд схеми хроматограми сухого екстракту стулок квасолі із зазначенням положення вибраних активних маркерів срлавоноїдів, а також двох неідентифрікованих сполук із фрлавоноїдів та гідроксикоричних кислот.

3. Кількісним критерієм якості сухого екстракту стулок квасолі запропоновано вміст фрлавоноїдів - не менше 0,65 \% у перерахунку на рутин і суху речовину.

\section{СПИСОК ЛІТЕРАТУРИ}

1. Державна Фармакопея України : в 3 т. / Державне підприємство "Український науковий фрармакопейний центр якості лікарських засобів". - 2-ге вид. Харків : Державне підприємство "Український науковий фармакопейний центр якості лікарських засобів", 2015. - T. 1. - 1128 c.

2. Stanislaw Kohlmünzer. Farmakognozja/ Stanislaw Kohlmünzer. - Warszawa, 2007. - 595 s.

3. Effect of aqueous extract from phaseolus vulgaris pods on lipid peroxidation and antioxidant enzymes activity in the liver and kidney of diabetic rats / M. Yu. Kyznetsova, O. M. Makieieva, D. O. Lavrovska [et al.] // J. of Applied Pharmaceutical Science. - 2015. - 5 (05). - 6 p. [Електронний ресурс]. - Режим доступу: http:/www. japsonline.com.

4. Reducing effect of a phaseolus vulgaris dry extract on food intake, body weight, and glycemia in rats / N. Fantini, C. Cabras, C. Lobina [et al.] // J. Agric. Food Chem. 2009. - Iss. 57. - P. 9316-9323.

5. Yurchenko A. The influence of kidney beans (Phaseolus vulgaris) pods extract on obesity development / A. Yurchenko, N. Raksha, O. Savchuk // Вісн. Київ. Нац. ун-ту ім. Тараса Шевченка (серія біологія). - 2016. № 2 (72). - C. 86-88.

6. Effect of aqueous extract of Phaseolus Vulgaris $L$. (Red Kidney Beans) on alloxan-induced diabetic wistar rats / C. D. Luca, A. Olatunde, H. Tijjani, I. A. OlisaEnewe // Int. J. of Science Invention Today. - 2013. - 2, Iss. 4. - P. 292-301.

7. Oonsivilai Ratchadaporn. Extraction condition of Phaseolus vulgaris / Ratchadaporn Oonsivilai, Jutarat Manatwiyangkool, Anant Oonsivilai // International Journal of Nutrition and Food Engineering. - 2011. - 12, No. 12. P. 869-872.

8. Zou Y. P. Antioxidant and proliferative properties of extract and fractions from small red bean (Phaseolus
Vulgaris L.) / Y. P. Zou, K. C. Sam Chang // J. Food and Nutrition. - 2014. - 1 (105). - 11 p.

9. Пат. 101850 Україна, МПКА61К 36/48 (2006.01), A61P 3/10 (2006.1). Спосіб одержання комплексу біологічно активних речовин 3 гіпоглікемічною дією / Ковальов В. М., Ковальов С. В., Демешко О. В., Дмитрієвський Д. І., Куцанян А. С., Малоштан Л. М. ; заявник і патентовласник Ковальов С. В. - № u 201413119 ; заявл. 08.12.14 ; опубл. 12.10.15, Бюл. № 19.

10. Tundis, R. Natural products as a-amylase and a-glucosidase inhibitors and their hypoglycaemic potential in the treatment of diabetes: an update / R. Tundis, M. R. Loizzo, F. Mennichini // Mini-Reviews in Medical Chemistry. - 201. - 10, No. 4. - P. 315-331.

11. Barret M. L. A proprietary alpha-amylase inhibitor from white bean (Phaseolus vulgaris): a review of clinical studies on weight loss and glycemic control / M. L. Barret, Jay K. Udani // Nutrition Journal. - 2011. - 10. - Art. 24. doi.org/10.1186/1475-2891-10-24.

12. Вронська Л. В. Дослідження зі стандартизації стулок плодів квасолі за вмістом фрлавоноїдів / Л. В. Вронська // Фармац. часоп. - 2013. - № 4. C. 82-87.

13. Vronska L. V. Development of phenolic compounds chromatographic identification in bilberry shoots / L. V. Vronska, M. B. Chubka, A. Ye. Demyd // Фармацевтичний часопис. - 2015. - № 3. - C. 28-33.

14. The polyphenolic profiles of common bean (Phaseolus vulgaris L.) / Long-Ze Lin, J. M. Harnly, M. S. Pastor-Corrales, D. L. Luthria // Food Chem. 2014. - 107 (1). - P. 399-410.

15. Kumar Ganesan, Baojun Xu. Polyphenol-Rich Dry Common Beans (Phaseolus vulgaris L.) and Their Health Benefits / Kumar Ganesan, Baojun Xu // International J. of Molecular Sciences. - 2017. - 18. - 26 p. [Електронний ресурс]. - Retrieved from: www.mdpi. com/journal/ijms. 


\section{REFERENCES}

1. (2015). Derzhavna Farmakopeia Ukrainy: $v 3 t$. [State Pharmacopeia of Ukraine]. Kyiv: Ukrainskyi naukovyi farmakopeinyi tsentr yakosti likarskykh zasobiv [in Ukrainian].

2. Kohlmünzer, S. (2007). Farmakognozja. Warszawa.

3. Kyznetsova, M.Yu., Makieieva, O.M., Lavrovska D.O., Tymoshenko, M.O., Sheverova, D.P., Halenova, T.I., ... Ostapchenko, L.I. (2015). Effect of aqueous extract from phaseolus vulgaris pods on lipid peroxidation and antioxidant enzymes activity in the liver and kidney of diabetic rats. J. of Applied Pharmaceutical Science, 5(05). Electronic resource: www.japsonline.com.

4. Fantini, N., Cabras, C., Lobina, C., Colombo, G., Gessa, G. L., Riva A. ... Mauro A. M. Carai (2009). Reducing effect of a phaseolus vulgaris dry extract on food intake, body weight, and glycemia in rats. J. Agric. Food Chem., 57, 9316-9323.

5. Yurchenko, A., Raksha, N., \& Savchuk, O. (2016). The influence of kidney beans (Phaseolus vulgaris) pods extract on obesity development. Visn. Kyyiv. Nats. un-tu im. Tarasa Shevchenka (seriya biolohiia) - Journal of Taras Shevchenko Kyiv National University, 2 (72), 86-88.

6. Luca, C.D., Olatunde, A., Tijjani, H., \& Olisa-Enewe, I. A. (2013). Effect of aqueous extract of Phaseolus Vulgaris L. (Red Kidney Beans) on alloxan-induced diabetic wistar rats. Int. J. of Science Invention Today, 2 (4), 292-301.

7. Oonsivilai Ratchadaporn, Jutarat Manatwiyangkool, Anant Oonsivilai. (2011). Extraction condition of phaseolus vulgaris. International Journal of Nutrition and Food Engineering, 12 (12), 869-872.

8. Zou Y.P., \& Chang Sam K.C. (2014). Antioxidant and proliferative properties of extract and fractions from small red bean (Phaseolus Vulgaris L.). J. Food and Nutrition, 1 (105), 11.

9. Kovalov, V.M., Kovalov, S.V., Demeshko, O.V., Dmytriievskyi, D.I., Kutsanian, A.S., Maloshtan, L.M. inventors; Kovalov, S.V., assignee. Sposib oderzhannia kompleksu biolohichno aktyvnykh rechovyn z hipohlikemichnoiu diieiu UA 101850 (Patent) 2006 Jan 10 [in Ukrainian].

10. Tundis, R., Loizzo, M. R., Mennichini, F. (2001). Natural products as $\alpha$-amylase and $\alpha$-glucosidase inhibitors and their hypoglycaemic potential in the treatment of diabetes: an update. Mini-Reviews in Medical Chemistry, 10 (4), 315-331.

11. Barret, M.L., \& Udani, Jay K. (2011). A proprietary alpha-amylase inhibitor from white bean (Phaseolus vulgaris): a review of clinical studies on weight loss and glycemic control. Nutrition Journal, 10 (24). doi. org:10.1186/1475-2891-10-24.

12.Vronska, L.V. (2013). Doslidzhennia zi standartyzatsii stulok plodiv kvasoli za vmistom flavonoidiv [Study of the standardization of valves fruit bean on flavonoid content]. Farmatsevtychnyi chasopys, 4, 82-87 [in Ukrainian].

13. Vronska, L.V., Chubka, M.B., \& Demyd, A.Ye. (2015). Development of phenolic compounds chromatographic identification in bilberry shoots. Farmatsevtychnyi chasopys, 3, 28-33.

14. Lin, Long-Ze, Harnly, J.M., Pastor-Corrales, M.S., \& Luthria, D.L. (2014). The polyphenolic profiles of common bean (Phaseolus vulgaris L.). Food Chem., 107 (1), 399-410.

15. Kumar Ganesan, \& Baojun Xu. (2017). Polyphenol-rich dry common beans (Phaseolus vulgaris L.) and their health benefits. International J. of Molecular Sciences, 18, 26. Electronic resource: www.mdpi.com/journal/ijms.

\section{СТАНДАРТИЗАЦИЯ СУХОГО ЭКСТРАКТА СТВОРОК ФАСОЛИ ПО СОДЕРЖАНИЮ ФЛАВОНОИДОВ}

\section{Резюме}

Вступление. Создание новых лекарственных средств для лечения и профилактики сахарного диабета - задача, которая приобретает все большую актуальность в условиях роста заболеваемости диабетом. Известно сахароснижающее действие отваров створок фрасоли. Разработка технологии сухого экстракта створок фрасоли, изучение его гипогликемического действия не возможны без установления состава экстракта и его стандартизации.

Цель исследования - разработка методики идентификации сухого экстракта створок фрасоли; разработка методики количественного определения фрлавоноидов; наработка критериев качества экстракта.

Методы исследования. Качественный состав фрлавоноидов исследовали хроматографрическими методами, количественное определение осуществляли спектрофотометрическим методом.

Результаты и обсуждение. Исследование фенольных соединений сухого экстракта створок фасоли хроматографическими методами позволили идентифицировать рутин, изокверцитрин, кислоту 
фреруловую, а также в следовом количестве кверцитрин. Кроме указанных френольных соединений, экстракт в значительном количестве содержит: неидентифицированный фрлавоноид, зона которого на тонкослойной хроматограмме располагается между зонами рутина и кислоты хлорогеновой; две гидроксикоричные кислоты, зоны которых находятся ниже и выше зоны кислоты фреруловой и, вероятно, могут быть ее производными; неидентифицированную гидроксикоричную кислоту, зона которой располагается сразу над зоной рутина. Анализ электронных спектров поглощения раствора стандартного образца рутина и испытуемого раствора сухого экстракта в условиях количественного определения с алюминия хлоридом позволил применить рутин в качестве стандарта для расчета содержания фрлавоноидов. Содержание фрлавоноидов было определено спектрофотометрическим методом, оно составило 0,70-0,78 \% в пересчете на рутин и сухое вещество для различных серий экстракта.

Выводы. Для идентификации сухого экстракта створок фрасоли активными маркерами предложено выбрать рутин, изокверцитрин и кислоту фреруловую. Предложена схема хроматограммы, которой должна соответствовать хроматограмма испытуемого раствора при идентифрикации сухого экстракта. Количественным критерием качества предложено содержание фрлавоноидов - не менее 0,65 \% в пересчете на рутин и сухое вещество.

КЛЮЧЕВЫЕ СЛОВА: створки фасоли; сухой экстракт; флавоноиды; стандартизация.

L. V. Vronska

I. HORBACHEVSKY TERNOPIL STATE MEDICAL UNIVERSITY

\section{STANDARDIZATION OF PHASEOLUS VULGARIS PODS DRY EXTRACT ON THE CONTENT OF FLAVONOIDS}

\section{Summary}

Introduction. The development of new drugs for treatment and prevention of diabetes is a challenge that is an urgent matter in the context of the increase of diabetes morbidity. The hypoglycemic effect of phaseolus vulgaris pods infusion is established. The development of technology of phaseolus vulgaris pods dry extract, the study of its hypoglycemic effect is possible only by determination of the composition of the extract and its standardization.

The aim of the study - to develop methods of phaseolus vulgaris pods dry extract identification; to develop and validate the technique of quantitative determination of flavonoids; to advance the quality criteria of the extract.

Research Methods. Qualitative composition of flavonoids was investigated by means of chromatographic methods; quantitative determination was conducted by spectrophotometric technique.

Results and Discussion. The research of phenolic compounds of phaseolus vulgaris pods dry extract by chromatographic methods allowed identifying rutin, isoquercitrin, ferulic acid and quercitrin in trace amounts. In addition to the phenolic compounds, the extract contained a large quantity of an unidentified flavonoid, a zone of which on the thin-layer chromatogram was situated between the zones of chlorogenic acid and rutin; two hydroxycinnamic acids, the zones of which were below and above the ferulic acid, and probably were their derivatives. The analysis of electronic spectra of absorption of a standard rutin sample solution and a dry extract test solution within the conditions of quantitative determination with aluminum chloride allowed using rutin as a standard for evaluation of flavonoids content. The content of flavonoids was determined by the spectrophotometric method, it was $0.7-0.8 \%$ range expressed in rutin and dry substance for different series of the extract.

Conclusions. To identify the dry extract of phaseolus vulgaris pods it was suggested to choose rutin, isoquercitrin and ferulic acid as active markers. The scheme of the chromatogram, which should be corresponded to the chromatogram of the test solution with the identification of dry extract, was recommended. The content of flavonoids was advised as a quantitative criterion of quality: not less than $0.65 \%$ expressed in rutin and dry substance.

KEY WORDS: phaseolus vulgaris pods; dry extract; flavonoids; standardization.

Отримано 10.01.18

Адреса для листування: Л. В. Вронська, Тернопільський державний медичний університет імені І. Я. Горбачевського, майдан Волі, 1, Тернопіль, 46001, Україна, e-mail: vronska_liudmyla@ukr.net. 